\title{
Pengujian Karakter-Karakter Kuantitatif Tajuk dan Umbi Klon-Klon Ubi Jalar (Ipomea batatas L.) Asal Maluku
}

\section{Testing Quantitative Characters of Crown and Tuber of Sweet Potato Clones (Ipomea batatas L.) from Maluku}

\section{Genesis Pattiserlihun', Meitty L. Hehanussa ${ }^{2, *}$}

\author{
${ }^{1}$ Program studi Agroteknologi, Jurusan Budidaya Pertanian, Fakultas Pertanian, Universitas Pattimura \\ ${ }^{2}$ Jurusan Budidaya Pertanian, Fakultas Pertanian, Universitas Pattimura \\ Jl. I. M. Puttuhena, Kampus Poka Ambon, 97233 \\ *E-mail Penulis Korespondensi: meitty.hehanussa@faperta.unpatti.ac.id
}

\begin{abstract}
This study aimed to examine the quantitative characters of crowns and tuber of sweet potato clones from Maluku. The research was conducted on the field near the building of the Research Institute of Pattimura University, in Rumahtiga Village, from March to August 2017. This research was done as a single factor experiment, that tested 21 sweet potato clones. The experimental design used was a completely randomized block design. The experiment was conducted with 3 replications so that there were 63 experimental units. Data analysis was carried out by analysis of variance with the $F$ test, and if there was a significant effect, the analysis was continued with the Duncan New Multiple Range Test at an $\alpha=0,05$. The variables observed included stem length, number of green leaves, stem length, individual leaf area, number of branches, length of the tuber, tuber diameter, number of tuber per plant and weight of fresh storage roots per plant. From this study, it was found that vegetative variables including stem segment length, number of branches, number of leaves and leaf area showed very significant differences among 19 local clones of sweet potatoes from Maluku and 2 clones of national superior varieties tested. Yield variables of tuber length, tuber number per plant and fresh tuber weight per plant showed very significant differences among 19 local sweet potato clones from Maluku and two national superior varieties clones tested, meanwhile tuber diameter showed significant differences. B9, BR5, H1, A13, ARl, and A15 clones produced average fresh tuber weight per plant above the national varieties of Cilembu and Antin 2.
\end{abstract}

Keywords: local clones, Maluku, sweet potato, vegetative character, yield

\section{ABSTRAK}

Penelitian ini bertujuan untuk menguji karakter-karakter kuantitatif tajuk dan umbi klon-klon ubi jalar asal Maluku. Penelitian dilaksanakan di lahan di belakang gedung Lembaga Penelitian Universitas Patimura Ambon, Desa Rumahtiga pada bulan Maret sampai bulan Agustus 2017. Percobaan ini merupakan percobaan faktor tunggal, yaitu pengujian 21 klon ubi jalar. Rancangan percobaan yang digunakan adalah rancangan acak lengkap berblok. Percobaan dilakukan dengan 3 ulangan, sehingga terdapat 63 satuan percobaan. Analisis data pengamatan dilakukan dengan analysis of variance dengan uji $\mathrm{F}$, dan apabila terdapat pengaruh yang nyata maka analisis diteruskan dengan uji lanjut menggunakan uji pembandingan rata-rata Duncan New Multiple Range Test pada taraf nyata $\alpha=0,05$. Peubah-peubah yang diamati meliputi panjang ruas batang, jumlah daun hijau, panjang batang, luas individu daun, jumlah cabang, panjang umbi, diameter umbi, jumlah umbi per tanaman dan bobot umbi segar per tanaman. Dari penelitian ini didapatkan bahwa peubah-peubah vegetatif yang meliputi panjang ruas batang, panjang batang, jumlah cabang, jumlah daun dan luas daun menunjukkan adanya perbedaan yang sangat nyata di antara 19 klon lokal ubi jalar asal Maluku dan dua klon varietas unggul nasional yang diuji. Peubah-peubah produksi panjang umbi, jumlah umbi per tanaman dan berat umbi segar per tanaman menunjukkan adanya perbedaan yang sangat nyata di antara 19 klon lokal ubi jalar asal Maluku dan dua klon varietas unggul nasional yang diuji, sedangkan diameter umbi menunjukkan adanya perbedaan yang nyata. Klon-klon B9, BR5, H1, A13, AR1 dan A15 menghasilkan rata-rata berat umbi segar per tanaman di atas varietas nasional Cilembu dan Antin 2.

Kata kunci: karakter vegetatif, klon-klon lokal, produksi, ubi jalar, Maluku 


\section{PENDAHULUAN}

Ubi jalar [Ipomoea batatas L.) Lam.] merupakan salah satu tanaman pangan sumber karbohidrat penting, selain padi, jagung, sagu, ubi kayu dan umbi-umbian lainnya. Ubi jalar sering disebut sebagai sumber pangan masa depan (Setyono et al., 1993). Selain untuk pangan, ubi jalar juga dapat di gunakan untuk pakan ternak dan bahan baku industri. Sebagian besar produksi ubi jalar di Indonesia digunakan sebagai bahan pangan dengan tingkat konsumsi per kapita 6,6 kg/tahun (Handewi dan Rachman, 2010). Namun pemanfaatannya masih terbatas pada bentuk makanan tradisional, seperti ubi goreng/rebus, kolak, getuk, kripik dan saos. Ginting et al. (2012) mengemukakan bahwa diversifikasi pengolahan ubi jalar menjadi beragam produk pangan, sehingga diharapkan dapatmeningkatkan citra dan konsumsi ubi jalar sekaligus nilai tambah produknya. Ubi jalar di Provinsi Maluku, khususnya di Kabupaten Seram Bagian Barat, sebagian besar digunakan sebagai makanan pokok selain beras dan sagu, namun belum dikembangkan menjadi berbagai bentuk makanan olahan.

Pemanfaatan ubi jalar sebagai alternatif bahan pangan semakin mendapat perhatian dalam upaya diversifikasi pangan di Indonesia. Hal ini karena umbi ubi jalar mengandung kalori dan karbohidrat yang tinggi. Ubi jalar memiliki potensi kalori sebesar 215 $\mathrm{kal} / \mathrm{ha} / \mathrm{hari}$ (Rukmana, 1997), sedangkan padi dan jagung berturut-turut hanya 176 dan $110 \mathrm{kal} / \mathrm{ha} / \mathrm{hari}$. Ubi jalar juga mengandung berbagai vitamin dan mineral serta kandungan gizi lain, seperti protein dan lemak. Karena itulah ubi jalar merupakan satu komoditas pertanian penghasil karbohidrat penting sebagai cadangan pangan bila produksi padi dan jagung tidak mencukupi. Di daerah yang memiliki produksi tinggi, ubi jalar dapat dijadikan bahan pangan alternatif menggantikan beras dan jagung. Sebagaimana jenis tanaman pangan lain, kendala utama dalam penggunaan ubi jalar sebagai bahan baku industri makanan adalah tidak tersedianya umbi sepanjang tahun (Setiawati et al., 1994).

Kandungan gizi ubi jalar adalah karbohidrat, mineral, dan vitamin. Komposisi zat gizi pada ubi jalar putih, Kuning, dan ungu yang sama namun varietas uni jalar ungu lebih kaya akan kandungan vitamin A yang Mencapai $7.700 \mathrm{mg}$ per $100 \mathrm{~g}$, ratusan kali lipat dari kandungan vitamin A bit dan tiga kali lipat dari tomat. Setiap $100 \mathrm{~g}$ ubi jalar ungu mengandung energi 123 kkal, protein $1,8 \mathrm{~g}$, lemak $0,7 \mathrm{~g}$, kalsim $30 \mathrm{mg}$, fosfor 49 $\mathrm{mg}$, besi 0,7 mg, vitamin A 7,700 SI, vitamin C $22 \mathrm{mg}$ dan vitamin B1 0,09 mg. Kadungan betakaroten, vitamin E dan vitamin $\mathrm{C}$ bermanfaat sebagai antioksida pencegah kanker (Nurhamidah dan Erawati, 2014).

Sentra produksivitas ubi jalar adalah Provinsi Jawa Barat, Papua, Jawa Timur, Sumatera Barat, Jawa Tengah dan Sumatera Utara (Badan Pusat Statistik, 2015). Menurut BPS (2015), produksivitas ubi jalar di Maluku selama ini masih tergolong rendah (10,950 t/ha) jika dibandingkan dengan potensi hasil varietas unggul yang bisa mencapai 40 t/ha. Hal ini antara lain disebabkan karena petani masih menggunakan varietas lokal dengan teknologi budidaya yang masih sederhana. Potensi hasil ubi jalar varietas lokal umumnya rendah, namun sebenarnya ada kemungkinan mengandung gengen pembawa sifat unggul, seperti daya adaptasi yang lebih baik atau ketahanan terhadap hama dan penyakit tertentu. Oleh sebab itu, plasma nutfah ubi jalar lokal perlu dikaji sifat-sifat baiknya melalui kegiatan karakterisasi.

Pengunaan klon-klon ubi jalar yang berproduktivitas rendah dan kurang adaptif terhadap lingkungan menyebabkan rendahnya produksi ubi jalar selama ini (Trisnawati et al., 2006). Oleh karena itu, perlu adanya upaya perbaikan produksi ubi jalar melalui penggunaan klon-klon baru menggantikan yang sudah lama dan produksinya relatif rendah (International Potato Center, 2000). Tersedianya klon-klon unggul dapat memberikan harapan yang berpotensi untuk dilepaskan sebagai varietas unggul baru. Peluang menambah varietas unggul baru cukup besar dengan adanya usaha introduksi varietas lokal dari Maluku. Dengan demikian, klon-klon lokal asal Maluku yang banyak jumlahnya perlu dikaji sifat-sifat baik dan produktivitasnya.

\section{METODE PENELITIAN}

\section{Tempat dan waktu penelitian}

Penelitian dilaksanakan di lahan di belakang gedung Lembaga Penelitian Universitas Patimura Ambon, Desa Rumahtiga pada bulan Maret sampai bulan Agustus 2017.

\section{Bahan dan Alat Penelitian}

\section{Bahan Penelitian}

Bahan-bahan yang digunakan dalam penelitian ini adalah setek batang dari 21 klon ubi jalar, yang terdiri dari 19 klon lokal hasil koleksi dari beberapa kabupaten di Propinsi Maluku dengan warna daging umbi ungu, orange dan kuning, dan 2 varietas nasional sebagai pembanding, yaitu varietas Cilembu dan varietas Antin. Bahan-bahan lainnya berupa pupuk $\mathrm{KCl}$ dan pupuk NPK, pupuk kotoran hewan (ayam), insektisida pengendali serangga (Furadan, Dithane-M45 dan Azodrin), bahan untuk label, polibag (ukuran $30 \times$ $30 \mathrm{~cm}$ ) dan tanah sebagai media tanam, paranet, batang kayu, dan selang air.

\section{Alat Penelitian}

Alat-alat yang digunakan dalam penelitian ini adalah cangkul, penggaruk, hiter, parang, ember plastik, slang air, gembor, tang, palu, sprayer, oven untuk pengeringan brankasan tanaman, timbangan, meter, papan oles, penggaris, alat-alat pengambilan data, kamera untuk dokumentasi dan ATK. 


\section{Rancangan Penelitian}

Percobaan ini merupakan percobaan faktor tunggal, yaitu pengujian 21 klon ubi jalar. Rancangan percobaan yang digunakan adalah rancangan acak lengkap berblok. Percobaan dilakukan dengan 3 ulangan, sehingga terdapat 63 satuan percobaan.

\section{Pelaksanaan Penelitian}

\section{Persiapan Bahan Tanam}

Bahan tanaman ubi jalar diambil dari tanaman di kebun koleksi Fakultas Pertanian Universitas Pattimura, diperbanyak dengan menggunakan setek (2 -3 daun) dan ditanam pada polibag yang berisi media tanam. Pemeliharaan bahan tanam ini selama 2-3 bulan, sampai tanaman siap dipindahkan ke lahan penelitian. Pelabelan pada setiap polibag juga dilakukan untuk mempermudah pemindahan ke lahan penelitian. Pengendalian organisme pengganggu tanaman (OPT) dilakukan secara manual dan dengan pemberian Furadan $1 \mathrm{~g}$ per polibag. Pemupukan dengan NPK dilakukan 1 minggu setelah tanam, yaitu $2 \mathrm{~g}$ per polibag.

\section{Persiapan Lahan dan Pengolahan Tanah}

Lahan penelitian dibersihkan dari gulma dan kotoran lain, tanah diolah/dicangkul hingga tanah menjadi gembur, dilakukan pembagian blok-blok sebanyak 3 blok, pembuatan petak berukuran 3,5 $\mathrm{m} \times$ $1,5 \mathrm{~m} \times 40 \mathrm{~cm}$ dalam setiap blok, dan dibuat parit di antara petak percobaan sebagai saluran drainase. Tiap blok dibuat 21 petak, dengan jarak $50 \mathrm{~cm}$ antar petak dalam blok, sedangkan jarak antara blok $150 \mathrm{~cm}$. Tata letak blok dan petak pada lahan percobaan ditunjukkan pada Lampiran. Jarak tanam antar guludan $100 \mathrm{~cm}$, dan dalam guludan $25 \mathrm{~cm}$. Pada tiap petak terdapat 16 tanaman, yang terdiri dari 6 tanaman ubinan, 4 tanaman sampel, dan tanaman samping. Tanaman ubinan untuk pengambilan data hasil dan komponen hasil. Sedangkan tanaman sampel untuk pengukuran peubah pertumbuhan diambil secara acak pada setiap petak yang bukan tanaman ubinan.

\section{Penanaman}

Penanaman dilakukan dengan meggunakan setek batang dari setiap klon ubi jalar yang berasal dari tanaman induk berumur 2 bulan. Ukuran setek adalah \pm $25 \mathrm{~cm}$ atau mempunyai 2-3 buku batang dengan menyisakan 1 daun. Setek ditanam posisi tegak pada guludan dengan $2 / 3$ setek terbenam dalam tanah.

\section{Pemeliharaan Tanaman}

Pemeliharaan tanaman meliputi penyiraman, pemupukan, penyulaman, penyiangan, pembumbunan, pengairan dan pembalikan batang tanaman.

1. Penyiraman tanaman muda dilakukan secara rutin setiap hari sampai umur bibit di lapangan 1 bulan. Selanjutnya penyiraman di lakukan 2 hari sekali sampai panen, kecuali jika ada hujan atau kondisi tanah masih basah.

2. Pemupukan dilakukan dengan pemberian dengan pupuk kotoran hewan (ayam) sebanyak $5 \mathrm{~kg}$ per petak diberikan sebelum penanaman dan pupuk NPK (15:15:15) sebanyak $200 \mathrm{~kg} / \mathrm{ha}$ atau $5 \mathrm{~g}$ per tanaman yang diberikan 15 hari setelah tanam (HST). Pemupukan kedua diberikan pada 60 HST $300 \mathrm{~kg} / \mathrm{ha}$ NPK atau 7,5 g per tanaman.

3. Penyulaman dilakukan dua minggu setelah tanam untuk mengganti tanaman yang tidak tumbuh.

4. Penyiangan dilakukan untuk mencegah pertumbuhan gulma karena dapat menghambat pertumbuhan ubi jalar. Penyiangan dilakukan sebanyak dua kali, yaitu umur 21 dan 42 HST.

5. Pembubunan dilakukan untuk mempertahankan struktur tanah tetap gembur, serta untuk mencegah agar umbi tidak tersembur keluar. Pembubunan pertama dilakukan pada umur tanaman 42 HST bersamaan dengan penyiangan dan pembubunan kedua dilakukan umur 60 HST.

6. Pembalikan tajuk dilakukan untuk menghindari terbentuk akar/umbi-umbi kecil dari buku batang. Pembalikan batang dilakukan pada 60 HST bersamaan dengan pemupukan kedua, sedangkan pembalikan batang kedua pada umur 75 HST.

7. Pengendalian OPT menggunakan insektisida Azodrin dan fungisida Dithane M-45. Jika ada gejala serangan insektisida Furadan sebanyak $2 \mathrm{~g}$ per guludan ditabur pada saat tanam untuk mencegah gangguan serangga pada tanaman muda.

\section{Pengumpulan Data dan Pengamatan}

Pada saat penelitian dilakukan pengamatan terhadap peubah-peubah vegetative dan umbi. Karena terjadi kondisi lingkungan tumbuh yang diluar normah dan kurang mendukung pertumbuhan ubi jalar, maka pada penelitian ini juga diupayakan untuk mendapatkan data Klimatologi dari BMKG.

Karakter-karakter yang diamati selama penelitian adalah sebagai berikut:

1. Panjang ruas batang (cm): Diukur 5 ruas pada bagian tengah batang utama; terdiri dari 2 ruas pada bagian pangkal 2 bagian tengah dan 1 ruas terakhir di ujung;

2. Jumlah daun hijau: Dihitung keseluruhan jumlah daun hijau yang masih ada pada tanaman.

3. Panjang batang (cm): Diukur dari pangkal batang utama hingga ujung pucuk batang.

4. Luas individu daun $\left(\mathbf{c m}^{2}\right)$ : Diukur dengan menggunakan leaf area meter; yang diwakili oleh 2 daun ukuran besar, 2 daun ukuran sedang dan 1 daun ukuran kecil.

5. Jumlah cabang: Dihitung jumlah tiap cabang primer yang terbentuk dari batang utama.

6. Panjang umbi (cm): Diukur dari pangkal hingga ujung umbi.

7. Diameter umbi (cm): Diukur pada bagian lingkaran umbi terbesar menggunakan jangka 
sorong (yang diwakili oleh 1 umbi ukuran besar, 1 umbi ukuran sedang dan 1 umbi ukuran kecil).

8. Jumlah umbi per tanaman: Ditentukan dengan menghitung jumlah umbi yang terbentuk pada tanaman contoh.

9. Bobot umbi segar per tanaman (g): Ditimbang semua umbi per tanaman setelah umbi dipanen dan dibersihkan dari kotoran-kotoran yang menempel.

\section{Analisis Data}

Analisis data pengematan dilakukan dengan analysis of variance dengan uji F. Untuk peubahpeubah komponen hasil dan hasil, kartena datanya tidak menyebar normal, maka dilakukan transformasi $(\mathrm{X}+0,5)^{0,5}$. Karena untuk semua peubah pengamatan terdapat pengaruh yang nyata atau sangat nyata maka analisis diteruskan dengan uji lanjut menggunakan uji pembandingan rata-rata Duncan New Multiple Range Test (DNMRT) pada taraf nyata $\alpha=5 \%$.

\section{HASIL DAN PEMBAHASAN}

\section{Hasil}

Hasil analisis ragam menunjukkan bahwa semua peubah vegetatif, yaitu panjang ruas batang, panjang batang, jumlah cabang, jumlah daun dan luas daun menunjukkan adanya perbedaan yang sangat nyata (uji $\mathrm{F}, \alpha=1 \%$ ) pada klon-klon yang diteliti. Peubah produksi yang diamati, yaitu panjang umbi, jumlah umbi per tanaman dan bobot umbi segar per tanaman juga menunjukan adanya perbedaan yang sangat nyata. Diameter umbi menunjukan adanya perbedaan yang nyata (uji F, $\alpha=5 \%$ ) di antara klon-klon yang diteliti. Semua peubah vegetatif dan peubah hasil yang diamati menunjukkan adanya perbedaan yang sangat nyata, kecuali diameter umbi yang menunjukkan perbedaan nyata pada analisis keragaman, dan dengan demikian untuk semua peubah tersebut dilanjutkan dengan Uji Beda Duncan, dengan $\alpha=5 \%$.

Tabel 2 menunjukkan bahwa rataan panjang ruas batang bervariasi di antara klon-klon yang diuji dan berkisar antara $2,92 \mathrm{~cm}$ pada klon B-Sepa-U sampai $6,10 \mathrm{~cm}$ klon A13. Klon A13 memiliki rataan panjang ruas batang terpanjang $(6,10 \mathrm{~cm})$ diikuti oleh klon B5 $(5,85 \mathrm{~cm})$ dan klon B43 $(5,57 \mathrm{~cm})$ yang tidak berbeda nyata satu sama lain. Sedangkan klon-klon yang memiliki rataan panjang ruas batang terkecil adalah 2,92 $\mathrm{cm}$ pada klon B-Sepa-U 2,96 cm pada varietas Cilembu $3,09 \mathrm{~cm}$ pada klon B70, 3,42 cm pada klon B33 dan $3,59 \mathrm{~cm}$ yang tidak berbeda nyata satu sama lain. Data pada Tabel 1 menunjukkan bahwa rataan panjang batang bervariasi di antara klon-klon yang diuji, serta berkisar antara $137,33 \mathrm{~cm}$ pada klon B-Sepa-U sampai $570,33 \mathrm{~cm}$ pada klon B39.

Klon B39 memiliki rataan panjang batang terpanjang $(570,33 \mathrm{~cm})$ dan diikuti klon B65 $(502,67$ $\mathrm{cm}$ ) yang tidak berbeda nyata satu sama lain. Sedangkan klon/varietas yang memiliki rataan panjang batang terkecil adalah klon B-Sepa-U $(137,33 \mathrm{~cm})$, diikuti oleh klon B70 $(148,83 \mathrm{~cm})$, varietas Cilembu $(173,33 \mathrm{~cm})$ dan klon B33 $(212,83 \mathrm{~cm})$ yang tidak berbeda nyata satu sama lain.

Tabel 1. Panjang ruas batang, panjang batang, dan jumlah cabang 19 klon asal Maluku dan dua varietas ubi jalar sebagai pembanding

\begin{tabular}{|c|c|c|c|c|c|}
\hline No & Kode & Klon & Panjang Ruas Batang $(\mathrm{cm})$ & Panjang Batang $(\mathrm{cm})$ & Jumlah Cabang \\
\hline 1 & K 1 & AR 1 & 3,58 ghij & $275,50 \mathrm{de}$ & $7,50 \mathrm{a}$ \\
\hline 2 & K 2 & B 5 & $5,85 \mathrm{a}$ & $400,67 \mathrm{~b}$ & $5,00 \mathrm{c}$ \\
\hline 3 & K 3 & B 9 & 3,89 efghi & 231,33 def & $7,00 \mathrm{ab}$ \\
\hline 4 & K 4 & B 33 & 3,42 hij & 212,83 efg & $7,67 \mathrm{a}$ \\
\hline 5 & K 5 & B 39 & 3,95 efgh & 298,83 cde & $4,50 \mathrm{c}$ \\
\hline 6 & K 6 & B 43 & $5,57 \mathrm{ab}$ & 570,33 a & $4,33 \mathrm{c}$ \\
\hline 7 & K 7 & B 65 & $4,95 \mathrm{bc}$ & 502,67 a & $4,67 \mathrm{c}$ \\
\hline 8 & K 8 & B 70 & $3,09 \mathrm{ij}$ & $148,83 \mathrm{fg}$ & $7,00 \mathrm{ab}$ \\
\hline 9 & K 9 & B 82 & 3,93 efgh & 288,00 cde & $5,17 \mathrm{bc}$ \\
\hline 10 & K 10 & B 102 & $4,67 \mathrm{cde}$ & 302,67 cde & $5,00 \mathrm{c}$ \\
\hline 11 & K 11 & B-Sepa-U & $2,92 \mathrm{j}$ & $137,33 \mathrm{~g}$ & $7,00 \mathrm{ab}$ \\
\hline 12 & K 12 & A 13 & $6,10 \mathrm{a}$ & $385,00 \mathrm{bc}$ & $5,83 \mathrm{abc}$ \\
\hline 13 & K 13 & A 15 & 3,67 fghij & $312,50 \mathrm{bcd}$ & $5,83 \mathrm{abc}$ \\
\hline 14 & K 14 & H 1 & 4,13 defgh & 293,83 cde & $5,17 \mathrm{bc}$ \\
\hline 15 & K 15 & $\mathrm{AHT}-\mathrm{U}$ & 4,49 cdefg & $273,33 \mathrm{de}$ & $5,33 \mathrm{bc}$ \\
\hline 16 & K 16 & BR 5 & $3,95 \mathrm{efgh}$ & $296,67 \mathrm{cde}$ & $4,33 \mathrm{c}$ \\
\hline 17 & K 17 & TL 1 & 4,26 cdefg & 307,83 cde & $5,83 \mathrm{abc}$ \\
\hline 18 & K 18 & TL 8 & 3,86 efghi & $281,50 \mathrm{de}$ & $4,83 \mathrm{c}$ \\
\hline 19 & K 19 & $\operatorname{Lr} 2$ & $4,80 \mathrm{bcd}$ & $329,00 \mathrm{bcd}$ & $4,83 \mathrm{c}$ \\
\hline 20 & K 20 & Cilembu & $2,96 \mathrm{j}$ & $173,33 \mathrm{fg}$ & $6,17 \mathrm{abc}$ \\
\hline 21 & K 21 & Antin & $4,94 \mathrm{bc}$ & 293,17 cde & $5,33 \mathrm{bc}$ \\
\hline
\end{tabular}

Keterangan: Angka yang sama yang diikuti oleh huruf yang sama tidak berbeda nyata berdasarkan Uji Beda Duncan pada taraf $\alpha=$ 0,05 . 
Tabel 2. Jumlah daun dan luas daun 19 klon asal Maluku dan dua varietas ubi jalar sebagai pembanding

\begin{tabular}{|c|c|c|c|c|}
\hline No & Kode & Klon & Jumlah Daun & Luas Daun $\left(\mathrm{cm}^{2}\right)$ \\
\hline 1 & K 1 & AR 1 & $130,50 \mathrm{def}$ & $64,21 \mathrm{bcd}$ \\
\hline 2 & K 2 & B 5 & $159,33 \mathrm{bcd}$ & $66,15 \mathrm{bcd}$ \\
\hline 3 & K 3 & B 9 & $91,33 \mathrm{f}$ & $73,00 \mathrm{~b}$ \\
\hline 4 & K 4 & B 33 & $229,67 \mathrm{a}$ & $36,49 \mathrm{~g}$ \\
\hline 5 & K 5 & B 39 & $94,33 \mathrm{f}$ & $93,15 \mathrm{a}$ \\
\hline 6 & K 6 & B 43 & $95,67 \mathrm{ef}$ & $56,21 \mathrm{de}$ \\
\hline 7 & K 7 & B 65 & 141,00 cde & 56,36 de \\
\hline 8 & K 8 & B 70 & $122,00 \mathrm{def}$ & 61,70 bcde \\
\hline 9 & K 9 & B 82 & $94,00 \mathrm{f}$ & $64,96 \mathrm{bcd}$ \\
\hline 10 & K 10 & B 102 & $127,00 \mathrm{def}$ & $55,38 \mathrm{de}$ \\
\hline 11 & K 11 & B-Sepa-U & $180,33 \mathrm{bc}$ & $30,02 \mathrm{~g}$ \\
\hline 12 & K 12 & A 13 & 108,67 ef & 58,54 cde \\
\hline 13 & K 13 & A 15 & 107,33 ef & $53,45 \mathrm{de}$ \\
\hline 14 & K 14 & H 1 & $126,33 \mathrm{def}$ & 49,44 ef \\
\hline 15 & K 15 & AHT - U & $123,00 \mathrm{def}$ & 50,67 ef \\
\hline 16 & K 16 & BR 5 & $164,33 \mathrm{bcd}$ & 62,32 bcde \\
\hline 17 & K 17 & TL 1 & $90,00 \mathrm{f}$ & $70,53 \mathrm{bc}$ \\
\hline 18 & K 18 & TL 8 & $90,67 \mathrm{f}$ & $65,10 \mathrm{bcd}$ \\
\hline 19 & K 19 & $\operatorname{Lr} 2$ & 106,00 ef & 49,52 ef \\
\hline 20 & K 20 & Cilembu & $192,67 \mathrm{ab}$ & $15,47 \mathrm{~h}$ \\
\hline 21 & K 21 & Antin & $112,33 \mathrm{ef}$ & $39,25 \mathrm{fg}$ \\
\hline
\end{tabular}

Keterangan: Angka yang sama yang diikuti oleh humf yang sama tidak berbeda nyata berdasarkan Uji Beda Duncan pada taraf $\alpha=$ 0,05 .

Data pada Tabel 1 juga menunjukkan bahwa rataan jumlah cabang bervariasi di antara klon-klon yang diuji, serta berkisar antara 4,33 pada klon Br5 dan klon B43, sampai dengan 7,67 pada klon B33. Klon B33 memiliki rataan jumlah cabang terbanyak $(7,67)$ diikuti oleh klon-klon AR1 (7,50), klon B70, B-Sepa-U, B9 yang memiliki jumlah cabang sama (yaitu 7,00), varietas Cilembu $(6,17)$, klon A13, A15 dan TL1 memiliki jumlah cabang sama (yaitu 5,83) yang tidak berbeda nyata satu sama lain.

Sementara itu, klon-klon yang memiliki rataan jumlah cabang terkecil adalah klon Br5 dan B43 yang memiliki jumlah cabang sama (yaitu 4,33), diikuti oleh klon B39 (4,50), klon B65 (4.67), klon TL8 dan Lr2 dengan jumlah sama (yaitu 4,83), klon B5 dan B102 dengan jumlah sama (yaitu 5,00), klon H1 $(5,17)$, serta klon AHT-U dan varietas Antin dengan jumlah cabang sama (5,33), dan jumlah cabang pada klon-klon tersebut tidak berbeda nyata satu sama lain.

Rataan jumlah daun bervariasi di antara klonklon yang diuji. Rataan jumlah daun berkisar antara 94,00 pada klon TL1 sampai dengan 229,67 pada klon B33 (Tabel 2). Klon B33 memiliki rataan jumlah daun terbanyak diikuti oleh varietas Cilembu $(192,67)$ dan keduanya tidak berbeda nyata satu sama lain. Sedangkan klon-klon yang memiliki rataan jumlah daun terkecil adalah klon TL1 (dengan rataan jumlah daun $90,00)$, klon B9 $(91,33)$ klon B82 $(94,00)$, klon B39 $(94,33)$, klon B43 $(95,67)$, klon Lr2 $(106,00)$, klon A15 $(107,33)$, klon A13 $(108,67)$, varietas Antin $(112,33)$, klon B70 (122,00), klon AHT-U (123,00), klon H1
$(126,33)$ dan klon B102 $(127,00)$, yang kesemuanya tidak berbeda nyata satu sama yang lain menurut Uji Beda Duncan.

Data pada Tabel 2 juga memperlihatkan bahwa terdapat perbedaan rataan luas daun di antara klon-klon yang diuji. Rataan luas daun berkisar antara $15,47 \mathrm{~cm}^{2}$ pada varietas Cilembu sampai dengan $93,15 \mathrm{~cm}^{2}$ pada klon B39. Klon B39 memiliki rataan luas daun terbesar, yaitu $93,15 \mathrm{~cm}^{2}$, diikuti oleh dan berbeda nyata dengan rataan luas daun klon-klon B5 $\left(66,15 \mathrm{~cm}^{2}\right)$, TL8 $(65,10$ $\left.\mathrm{cm}^{2}\right)$, B82 $\left(64,96 \mathrm{~cm}^{2}\right)$, AR1 $\left(64,61 \mathrm{~cm}^{2}\right)$, BR5 $(62,32$ $\mathrm{cm}^{2}$ ) dan B7 (61,72), yang tidak berbeda nyata satu sama lain. Sedangkan varietas Cilembu memiliki rataan luas daun terkecil, yaitu $15,47 \mathrm{~cm}^{2}$, yang diikuti oleh dan tetapi berbeda nyata dengan klon-klon B-Sepa-U $\left(30,02 \mathrm{~cm}^{2}\right)$, B33 $\left(36,49 \mathrm{~cm}^{2}\right)$ dan varietas Antin $(39,25$ $\mathrm{cm}^{2}$ ), yang ketiganya tidak berbeda nyata satu sama lain.

Rataan panjang umbi bervariasi di antara klonklon yang diuji. Rataan panjang umbi berkisar antara $8.67 \mathrm{~cm}$ pada klon TL1 sampai dengan $19,90 \mathrm{~cm}$ pada varietas Antin (Tabel 3). Varietas Antin memiliki umbi terpanjang, yaitu 19,90 cm, diikuti oleh klon B-Sepa-U $(15,82 \mathrm{~cm})$ yang tidak berbeda nyata satu sama lain. Sedangkan klon-klon yang memiliki umbi terpendek adalah klon TL1 $(8.67 \mathrm{~cm} \mathrm{~cm})$ diikuti oleh klon A13 $(9,13 \mathrm{~cm})$, klon B70 $(10,25 \mathrm{~cm})$, klon Br5 $(10,25 \mathrm{~cm})$, klon B43 $(10,60 \mathrm{~cm})$, klon AHT-U $(10,78 \mathrm{~cm})$, klon B33 $(12,70 \mathrm{~cm})$, klon B39 $(11,01 \mathrm{~cm})$ dan klon B102 $(11,87 \mathrm{~cm})$, yang kesemuanya tidak berbeda nyata satu sama lainnya. 
Tabel 3. Panjang umbi dan diameter umbi 19 klon asal Maluku dan 2 varietas ubi jalar sebagai pembanding

\begin{tabular}{|c|c|c|c|c|c|c|}
\hline No & Kode & Klon & $\begin{array}{l}\text { Panjang Umbi } \\
(\mathrm{cm})(\mathrm{X})\end{array}$ & $\begin{array}{c}\text { Transformasi } \\
(X+0,5)^{0,5}\end{array}$ & $\begin{array}{l}\text { Diameter Umbi } \\
(\mathrm{cm})(\mathrm{Y})\end{array}$ & $\begin{array}{c}\text { Transformasi } \\
(\mathrm{Y}+0,5)^{0,5}\end{array}$ \\
\hline 1 & K 1 & AR 1 & 14,08 & $3,817 \mathrm{bc}$ & 2,67 & $1,777 \mathrm{abcd}$ \\
\hline 2 & K 2 & B 5 & 13,39 & $3,706 \mathrm{bcd}$ & 2,66 & 1,777 abcd \\
\hline 3 & K 3 & B 9 & 13,29 & $3,710 \mathrm{bcd}$ & 2,91 & $1,843 a b c$ \\
\hline 4 & K 4 & B 33 & 12,70 & 3,630 bcde & 2,39 & 1,687 abcdef \\
\hline 5 & K 5 & В 39 & 11,01 & 3, 377 bcde & 1,39 & 1,367 ef \\
\hline 6 & K 6 & B 43 & 10,60 & $3,313 \mathrm{cde}$ & 1,69 & 1,467 cde \\
\hline 7 & K 7 & В 65 & 13,40 & $3,720 \mathrm{bcd}$ & 2,20 & 1, 640 abcde \\
\hline 8 & K 8 & B 70 & 10,25 & 3, $267 \mathrm{cde}$ & 1,52 & $1,417 \mathrm{def}$ \\
\hline 9 & K 9 & B 82 & 14,65 & $3,793 \mathrm{bc}$ & 2,44 & 1,707 abcdef \\
\hline 10 & K 10 & B 102 & 11,87 & 3, 577 bcde & 2,17 & 1,600 abcdef \\
\hline 11 & K 11 & B-Sepa-U & 15,82 & $4,027 \mathrm{ab}$ & 3,60 & $1,997 \mathrm{a}$ \\
\hline 12 & K 12 & A 13 & 9,13 & $3,097 \mathrm{de}$ & 2,13 & 1,620 abcdef \\
\hline 13 & K 13 & A 15 & 13,04 & $3,860 \mathrm{bc}$ & 1,87 & 1,540 bcdef \\
\hline 14 & K 14 & H 1 & 13,25 & $3,703 \mathrm{bcd}$ & 2,60 & 1,713 abcdef \\
\hline 15 & K 15 & AHT-U & 10,78 & 3,353 cde & 2,48 & 1,723 abcdef \\
\hline 16 & K 16 & BR 5 & 10,25 & 3,270 cde & 2,55 & 1,743 abcde \\
\hline 17 & K 17 & TL 1 & 8,67 & $3,027 \mathrm{e}$ & 1,28 & $1,330 \mathrm{f}$ \\
\hline 18 & K 18 & TL 8 & 9,79 & 3,200 cde & 193 & 1,553 bcdef \\
\hline 19 & K 19 & $\operatorname{Lr} 2$ & 11,58 & 3,467 bcde & 1.76 & $1,497 \mathrm{cdef}$ \\
\hline 20 & K 20 & Cilembu & 11,23 & 3,420 bcde & 2.45 & 1,717 abcdef \\
\hline 21 & K 21 & Antin & 19,90 & $4,513 \mathrm{a}$ & 3.34 & $1,950 \mathrm{ab}$ \\
\hline
\end{tabular}

Keterangan: Angka yang sama yang diikuti oleh humf yang sama tidak berbeda nyata berdasarkan Uji Beda Duncan pada taraf $\alpha=$ 0,05 .

Tabel 4. Jumlah umbi per tanaman dan bobot umbi segar per tanaman 19 klon asal Maluku dan 2 varietas ubi jalar sebagai pembanding

\begin{tabular}{ccccccc}
\hline No & Klon & Kode klon & $\begin{array}{c}\text { Jumlah Umbi per } \\
\text { Tanaman }(\mathrm{X})\end{array}$ & $\begin{array}{c}\text { transformasi } \\
(\mathrm{X}+0,5)^{0,5}\end{array}$ & $\begin{array}{c}\text { Bobot Umbi Segar } \\
\text { per Tanaman }(\mathrm{g}) \mathrm{Y})\end{array}$ & $\begin{array}{c}\text { transformasi } \\
(\mathrm{Y}+0,5)^{0,5}\end{array}$ \\
\hline 1 & K 1 & AR 1 & 7.00 & $2.7333 \mathrm{bcde}$ & 168.83 & $12.980 \mathrm{abcd}$ \\
2 & K 2 & B 5 & 5.67 & $2.4800 \mathrm{def}$ & 132.00 & $11.297 \mathrm{abcde}$ \\
3 & K 3 & B 9 & 11.33 & $3.4067 \mathrm{abc}$ & 235.00 & $15.300 \mathrm{a}$ \\
4 & K 4 & B 33 & 7.00 & $2.7367 \mathrm{bcde}$ & 152.50 & $11.663 \mathrm{abcde}$ \\
5 & K 5 & B 39 & 2.17 & $1.6200 \mathrm{f}$ & 23.17 & $4.273 \mathrm{~g}$ \\
6 & K 6 & B 43 & 3.33 & $1.9100 \mathrm{ef}$ & 64.00 & $7.380 \mathrm{efg}$ \\
7 & K 7 & B 65 & 3.17 & $1.9000 \mathrm{ef}$ & 71.17 & $8.357 \mathrm{cdefg}$ \\
8 & K 8 & B 70 & 7.67 & $3.0000 \mathrm{abcd}$ & 97.67 & $9.810 \mathrm{bcde}$ \\
9 & K 9 & B 82 & 6.00 & $2.5433 \mathrm{cdef}$ & 102.00 & $9.927 \mathrm{bcde}$ \\
10 & K 10 & B 102 & 7.33 & $2.7467 \mathrm{bcde}$ & 92.17 & $8.997 \mathrm{cdefg}$ \\
11 & K 11 & Sepa - U & 6.00 & $2.4700 \mathrm{def}$ & 188.67 & $13.023 \mathrm{abcd}$ \\
12 & K 12 & A 13 & 14.67 & $3.7067 \mathrm{a}$ & 167.17 & $12.587 \mathrm{abcde}$ \\
13 & K 13 & A 15 & 11.83 & $3.4333 \mathrm{ab}$ & 111.75 & $10.297 \mathrm{abcde}$ \\
14 & K 14 & H 1 & 11.83 & $3.4933 \mathrm{ab}$ & 186.63 & $13.530 \mathrm{abc}$ \\
15 & K 15 & AHT - U & 5.00 & $2.3367 \mathrm{def}$ & 89.83 & $9.490 \mathrm{bcdef}$ \\
16 & K 16 & BR 5 & 12.00 & $3.5333 \mathrm{ab}$ & 220.67 & $14.753 \mathrm{ab}$ \\
17 & K 17 & TL 1 & 2.67 & $1.7533 \mathrm{f}$ & 20.50 & $4.513 \mathrm{fg}$ \\
18 & K 18 & TL 8 & 4.67 & $2.2700 \mathrm{def}$ & 67.67 & $8.140 \mathrm{defg}$ \\
19 & K 19 & Lr 2 & 4.00 & $2.0833 \mathrm{def}$ & 78.17 & $7.783 \mathrm{defg}$ \\
20 & K 20 & Cilembu & 4.50 & $2.2367 \mathrm{def}$ & 96.67 & $9.797 \mathrm{bcde}$ \\
21 & K 21 & Antin & 3.50 & $1.9900 \mathrm{ef}$ & 149.33 & $12.190 \mathrm{abcde}$ \\
\hline
\end{tabular}

Keterangan: Angka yang sama yang diikuti oleh huruf yang sama tidak berbeda nyata berdasarkan Uji Beda Duncan pada taraf $\alpha=$ 0,05 
Diameter umbi klon-klon dan varietas-varietas pembanding berkisar antara $1.28 \mathrm{~cm}$ pada klon TL1 sampai dengan 3,60 $\mathrm{cm}$ pada klon B-Sepa-U (Tabel 4). Klon yang memiliki diameter umbi terbesar adalah BSepa-U $(3,60 \mathrm{~cm})$ diikuti secara berturut-turut oleh oleh varietas Antin $(3.34 \mathrm{~cm})$, klon B9 $(2,91 \mathrm{~cm})$, klon Ar1 $(2,67 \mathrm{~cm})$ klon B5 $(2,66 \mathrm{~cm})$, klon Br5 $(2,55 \mathrm{~cm})$, klon AHT-U (2,48 cm), varietas Cilembu $(2.45 \mathrm{~cm})$, klon $\mathrm{H} 1$ $(2,60 \mathrm{~cm})$, klon B82 $(2,44 \mathrm{~cm})$, klon B33 $(2,39 \mathrm{~cm})$, klon B65 $(2,20 \mathrm{~cm})$, klon A13 $(2,13 \mathrm{~cm})$, dan klon B102 $(2,17 \mathrm{~cm})$, yang tidak berbeda nyata satu sama yang lain. Sedangkan klon-klon yang memiliki diameter umbi terkecil adalah klon TL1 $(1,28 \mathrm{~cm})$, yang diikuti secara berturut-turut oleh klon B39 (1,39 cm), klon B70 (1,52 $\mathrm{cm})$, klon A15 $(1,87 \mathrm{~cm})$ dan klon TL8 $(1193 \mathrm{~cm})$, yang tidak berbeda nyata satu sama lain.

Jumlah umbi per tanaman bervariasi di antara klon-klon yang diuji, yang berkisar antara berkisar antara 2,17 klon B39 sampai 14,67 pada klon A13 (Tabel 5). Klon A13 memiliki rata-rata jumlah umbi terbanyak $(14,67)$ diikuti oleh secara berturut-turut oleh klon Br5 $(12,00)$, klon H1 $(11,83)$, klon A15 $(11,83)$, klon B9 $(11,33)$ dan klon B70 $(7,67)$ tidak berbeda nyata satu sama lain. Klon-klon yang memiliki jumlah umbi per tanaman paling sedikit adalah B39 $(2,17)$, diikuti oleh klon TL1 $(2,67)$, klon B65 $(3,17)$, klon B43 $(3,33)$, varietas Antin $(3,50)$, klon Lr2 $(4,00)$, varietas Cilembu (4,50), klon TL8 $(4,67)$, klon AHT-U $(5,00)$, B5 $(5,67)$, dan klon B-Sepa-U $(6,00)$, yang tidak berbeda nyata satu sama lain,

Bobot umbi per tanaman juga bervariasi diantara klon-klon dan varietas-varietas yang diuji, Bobot umbi per tanaman berkisar antara 20,50 g pada klon TL1 sampai 239,00 g pada klon B9 (Tabel 4.5) Klon B9 memiliki rata-rata bobot umbi terbesar $(235,00 \mathrm{~g})$, diikuti secara berturut-turut oleh Br5 (220,67 g), klon BSepa-U (188,67 g), klon H1 (186,63 g),klon AR1 $(168,83 \mathrm{~g})$,dan klon A13(167,17 g), klon B33 (152,50 g), klon B5 (132,00 g) dan klon A15 (111,75 g), yang tidak berbeda nyata satu sama lain. Klon-klon yang memiliki bobot umbi segar per tanaman terkecil adalah klon TL1 (20,50 g), yang diikuti secara berturut-turut oleh klon B39(23,17 g), klon B43 (64,00 g), klon TL8 $(67,73 \mathrm{~g})$, klon B65 (71,17 g), klon Lr2 (78,17 g), dan B102 (92,17 g) yang tidak berbeda nyata satu sama yang lain,

\section{Pembahasan}

Pada penelitian ini, penanaman dilakukan pada awal bulan April 2017 dan percobaan berlangsung sampai bulan Juli 2017, Pada awal pertumbuhan tanaman, sesudah menanaman dilakukan penyiraman khususnya pada hari-hari bila tidak ada hujan, untuk menjamin pertumbuhan awal yang baik, Akan tetapi, pada bulan Mei, Juni dan Juli 2017 terjadi curah hujan yang sangat tinggi, yaitu masing-masing sebesar 753 mm, $1439 \mathrm{~mm}$ dan $1046 \mathrm{~mm}$. Pada bulan Mei jumlah hari hujan juga sangat tinggi, yaitu 29 hari, pada bulan
Juni 29 hari dan pada bulan Juli 27 hari; dengan penyinaran matahari masing-masing sebesar $40 \%, 2 \%$ dan 32\%, Ini berarti selama 3 bulan tersebut curah hujan dan jumlah hari hujan sangat tinggi sangat tinggi dan penyinaran matahari sangat rendah,

Curah hujan bulan Mei-Juli sangat tinggi dan kondisi tersebut telah menyebabkan lahan percobaan terendam dan akibatnya pertumbuhan dan perkembangan tanaman tidak optimal dan bahkan terhambat. Menurut Sarwono (2005), tanaman ubi jalar tidak tahan terhadap genangan air, tanah yang becek atau berdrainase buruk, yang dapat mengakibatkan tanaman tumbuh kerdil, daun menguning dan umbinya membusuk, Kondisi yang demikian dialami oleh sebagian tanaman pada penelitian ini. Selain itu pertumbuhan tanaman dan pembentukan umbi juga dihambat oleh tingkat penyinaran matahari yang rendah selama bulan Mei-Juli. Hasil pengamatan di lapang menunjukkan bahwa khususnya Blok/Ulangan 1 dan 2 mengalami kondisi tergenang karena hari-hari hujan yang berturut-turut, Sementara itu, untuk Blok 3 kurang tergenang karena kedudukan tanah lebih tinggi dibandingkan dengan Blok 1 dan 2, Walapun kondisi lahan sedemikian rupa tetapi beberapa klon asal Maluku dapat bertahan hidup dan membentuk umbi cukup baik dibandingkan dengan varietas nasional,

Hasil Anova memperlihatkan bahwa klon/varietas yang dikaji memiliki karakteristik tajuk maupun umbi yang berbeda-beda, sebagaimana ditunjukkan oleh data hasil pengamatan terhadap peubah-peubah pada tajuk dan umbi, Nilai peubah vegetatif yang baik ditunjukkan oleh klon K1 (AR1) untuk jumlah cabang, K2 (B5) dan K12 (A13) untuk panjang ruas batang, K4 (B33) untuk jumlah cabang dan jumlah daun, K5 (B39) untuk luas daun, K6 (B43) dan K7 (B63) untuk panjang batang, Klon-klon tersebut lebih mampu bertahan hidup dan tumbuh pada kondisi yang ada, serta mempunyai bagian vegetatif (daun, batang) yang lebih banyak, Hal ini menunjukan bahwa klon-klon tersebut mampu beradaptasi dengan lingkungannya (tanah, suhu, curah hujan dan kelembaban), selama penelitian, Klon-klon K1, K2, K4, $\mathrm{K} 5$, K6, K7, dan K12 dapat hidup dan tumbuh pada kondisi yang kurang baik, dalam hal ini curah hujan yang sangat tinggi dan adanya genangan pada lahan penelitian, Klon-klon tersebut yang dapat beradaptasi dengan kondisi yang kurang optimal dan dengan bagian vegetatif yang tumbuh baik kemungkinan dapat dikembangkan untuk bahan makanan ternak,

Perbedaan pertumbuhan antar klon terutama ditentukan oleh faktor genetik; dan potensi genetiknya akan lebih maksimal jika didukung oleh faktor lingkungan yang mendukung, Menurut Jambormias (2011) adaptasi spesifik lingkungan suatu genotype berkaitan dengan kemampuan suatu genotype untuk menunjukan keragaman terbaiknya pada suatu lingkungan spesifik, Perbedaan genetik tersebut dapat dilihat jika klon atau varietas yang berbeda ditanam pada lingkungan yang sama akan menunjukan 
perbedaan yang nyata (Fitter dan Hay, 1991), Lingkungan memberikan peran dalam rangka penampakan karakter yang sebenarnya dikendalikan oleh gen-gen tertentu. Setiap individu atau populasi tanaman menunjukan pertumbuhan dan hasil yang beragam sebagai akibat dari pengaruh genetik dan lingkungan. Pengaruh genetik merupakan pengaruh keturunan yang dimiliki oleh setiap varietas, sedangkan pengaruh lingkungan adalah pengaruh yang ditimbulkan oleh habitat dan kondisi lingkungan. Sitompul dan Guritno (1995) mengemukakan bahwa faktor genetik tanaman merupakan salah satu penyebab perbedaan antara tanaman satu dengan tanaman lainnya,

Daun merupakan organ fotosintesis utama, sehingga pengamatan daun sangat diperlukan sebagai indikator pertumbuhan juga sebagai data penunjang untuk menjelaskan proses pertumbuhan yang terjadi pada pembentukan biomasa (Sitompul dan Guritno, 1995), Meningkatnya jumlah daun sebagai organ fotosintesis akan meningkatkan pula laju fotosintesis jika daun-daun yang terbentuk tidak saling menaungi, dan ini akan menunjang pembentukan gula dan pati yang penting untuk pembentukan dan pembesaran umbi, Salisbury dan Ross (1991) menyatakan bahwa kapasitas fotosintesis meningkat dengan bertambahnya jumlah daun per tanaman, Hal ini disebabkan karena dengan bertambahnya jumlah daun maka luas bidang penyerapan cahaya akan semakin bertambah pula, dengan asumsi bahwa daun-daun tersebut berperan secara optimal, yaitu tidak tertutupi atau tidak terhalangi oleh daun-daun lainnya), Selanjutnya Gardner et al. (1991) mengemukakan bahwa semakin tinggi hasil fotosintesis semakin besar pula penimbunan cadangan makanan yang ditranslokasikan jika faktor lain, seperti cahaya, air, suhu dan hara dalam keadaan optimal, Dengan optimalnya laju fotosintesis yang terjadi pada daun sehingga akan memungkinkan lebih banyak asemilat dalam tanaman, Sementara itu, karakterkarakter atau peubah-peuban lainnya juga penting untuk proses fisiologis dan pembentukan umbi. Karakter pertumbuhan yang menyokong proses fisiologis yang efektif pada ubi jalar adalah percabangan banyak dan sulur yang pendek, Sedangkan komponen hasil yang penting meliputi jumlah umbi per tanaman serta panjang dan diameter umbi,

Suwardjono (2003) mengemukakan bila total luas daun meningkat, maka penerima cahaya matahari sebagai sumber utama dalam proses fotosintesis, akan meningkat dengan meningatnya fotosintesis diikuti peningkatan respirasi, menyebabkan proses metabolisme berlangsung lebih baik dan akan mendukung pertumbuhan dan perkembangan tanaman, yang diindikasikan oleh besarnya tajuk dan umbi. Hal ini sesuai dengan hasil penelitian Rahayuningsih et al. (1997) yang menunjukkan bahwa bobot tajuk yang tinggi pada klon ubi jalar juga menghasilkan umbi yang tinggi,

Sebagaimana diuraikan sebelumnya, pada penelitian ini rendahnya hasil disebabkan oleh curah hujan yang sangat tinggi, yang mengakibatkan kondisi lahan percobaan tergenang sehingga merusak tajuk yang sudah ada, menghambat pembentukan umbi, serta pada beberapa klon menyebabkan umbi yang sudah terbentuk menjadi busuk, Akibatnya rata-rata ukuran umbi (panjang dan diameter), jumlah umbi dan berat segar umbi per tanaman tidak mencapai nilai yang optimal, Dengan kata lain, kondisi lahan percobaan yang tergenang ini telah menyebabkan pengaruh yang negatif terhadap kemampuan tanaman untuk berproduksi secara optimal, yang selanjutnya menyebabkan hasilnya di bawah produktivitas klon-klon seandainya tumbuh pada kondisi yang tidak tergenang,

Menurut Goldsworthy dan Fisher (1992), komponen hasil yang penting meliputi jumlah umbi per tanaman dan diameter umbi, Proses pembentukan umbi pada tanaman ubi jalar sangat ditentukan oleh kondisi lahan, terutama pada saat awal pertumbuhan tanaman (lebih kurang umur 1 bulan), sehingga pada umur tersebut kondisi lahan telah diupayakan agar sesuai untuk pertumbuhan tanaman, Pada saat tersebut, kondisi cuaca masih menunjang pertumbuhan tanaman, Namun pada tahan pertumbuhan dan perkembangan tanaman selanjutnya, kondisi lingkungan kurang menunjang pertumbuhan dan perkembangan tamanan, khususnya pembentukan dan pembesaran umbi, Akibatnya, semua komponen hasil yang diamati, yakni panjang umbi, diameter umbi, jumlah umbi, dan hasil (berat umbi per tanaman) menghasilkan nilai yang rendah, Dapat dikatakan untuk semua klon dan varietas pembanding dalam penelitian ini tidak mencapai potensi daya hasilnya masing-masing,

Perbedaan pada masing-masing varietas atau klon, selain ditentukan oleh sifat genetik juga ditentukan oleh kesesuaiannya terhadap lokasi tumbuhnya, Varietas suatu tanaman, merupakan kelompok tanaman dengan ciri khas yang seragam dan stabil serta mengandung perbedaan yang jelas dari varietas lain, Demikian halnya dengan dua puluh satu varietas ubi jalar yang digunakan dalam penelitian ini, karena adanya perbedaan karakteristik antar varietas sehingga sifat-sifat yang dimunculkan pun berbeda, karena dua puluh satu klon/varietas tersebut ditanam pada suatu kondisi lingkungan yang diupayakan seseragam mungkin. Bari et al. (1974), menyatakan bahwa lingkungan merupakan pembentuk akhir suatu organisme, dan keragaman sebagai akibat faktor lingkungan dan keragaman genetik umumnya berinteraksi satu sama lain dalam mempengaruhi penampilan fenotipe tanaman, Faktor genetik tidak akan memperlihatkan sifat yang dibawanya kecuali dengan adanya faktor lingkungan yang diperlukan, Hal ini juga berlaku untuk karakter hasil ubi jalar berupa berat segar umbi per tanaman; yang tidak akan mencapai nilai yang optimal jika tanaman tidak tumbuh pada lingkungan yang optimal,

Dari hasil penelitian ini didapatkan bahwa 6 klon lokal menghasilkan rata-rata berat umbi per tanaman di atas varietas pembanding K21 (Antin), Klon-klon lokal tersebut adalah K3 (B9), K16 (Br5), K14 (H1), K11 (B Sepa-U), K1 dan K12 (A13), yang masing-masing berat umbi tertanamannya secara berturut-turut $25,5 \%$, 
$21,0 \%, 11,0 \%, 8,5 \%, 6,5 \%$ dan 3,3\% di atas berat umbi ter tanaman pada varietas Antin, Di samping 6 klon tersebut, K2, K4, K13, K9 dan K8 menghasilkan ratarata berat umbi ter tanaman di atas varietas pembanding K20 (Cilembu), Hal ini menunjukkan bahwa di antara 19 klon lokal yang dikaji dalam penelitian ini, banyak di antaranya yang mampu memproduksi umbi di atas produksi umbi pada kedua varietas pembanding (Antin dan Cilembu), Klon-klon tersebut kemungkinan lebih mampu beradaptasi dengan kondisi pada saat penelitian, yaitu curah hujan yang sangat tinggi dan dan penyinaran matahari yang rendah,

Pada penelitian ini, tiga klon yang memiliki ratarata bobot umbi terbesar adalah $\mathrm{B} 9(239,00 \mathrm{~g})$, diikuti secara berturut-turut oleh Br5 $(220,67 \mathrm{~g})$ dan klon BSepa-U (188,67 g), Jika ini dikonversikan ke ton per hektar, dengan populasi tanaman 40 ribu tanaman per hektar berdasarkan jarak tanaman $100 \mathrm{~cm} \times 25 \mathrm{~cm}$, maka hasil panen dalam bobot umbi segar klon-klon B9, Br5 dan B-Sepa-U masing-masing adalah 9,40 t/ha, 8,83 t/ha dan 7,55 t/ha, Tiga klon yang memiliki bobot umbi segar per tanaman terkecil adalah klon TL1 (20,50 g), B39 $(23,17 \mathrm{~g})$ dan B43 $(64,00 \mathrm{~g})$, yang jika ini dikonversikan ke ton per hektar adalah berturut-turut sebesar 0,82 t/ha, 0,93 t/ha dan 2,56 t/ha,Sementara itu, dua varietas pembanding, yaitu Cilembu dan Antin 2, dengan hasil dalam bobot umbi per tanaman masingmasing sebesar 96,67 g dan 149,33 g, jika dikonversikan sebesar 3,22 t/ha dan 4,89t/ha, Ini jauh lebih rendah daripada potensi hasil dari masing-masing varietas tersebut sesuai deskripsinya, yakni 30-35 t/ha untuk Cilembu dan 33,2 t/ha untuk Antin (BALITKABI, 2016).

\section{KESIMPULAN}

Dari penelitian yang telah dilaksanakan dapat disimpulkan bahwa 19 klon lokal ubi jalar asal Maluku yang diuji dan 2 varietas unggul nasional (Cilembu dan Antin) menunjukkan karakteristik vegetatif tajuk dan hasil umbi yang berbeda-beda. Peubah-peubah vegetatif yang meliputi panjang ruas batang, panjang batang, jumlah cabang, jumlah daun dan luas daun menunjukkan adanya perbedaan yang sangat nyata di antara 19 klon lokal ubi jalar asal Maluku yang diuji dan 2 varietas unggul nasional. Peubah-peubah produksi panjang umbi, jumlah umbi per tanaman dan berat umbi segar per tanaman menunjukkan adanya perbedaan yang sangat nyata di antara 19 klon lokal ubi jalar asal Maluku yang diuji dan 2 varietas unggul nasional, sedangkan diameter umbi menunjukkan adanya perbedaan yang nyata. Terdapat 6 klon lokal menghasilkan rata-rata berat umbi segar per tanaman di atas varietas Cilembu dan Antin 2, yaitu B9, BR5, H1, A13, AR1 dan A15.

\section{UCAPAN TERIMA KASIH}

Kami menucapkan terima kasih kepada Kementerian Riset, Teknologi dan Pendidikan Tinggi, yang melalui Universitas Pattimura telah mendanai penelitian ini dengan dana penelitian skim Penelitian Produk Terapan Tahun 2018 dengan judul: "Produksi Kolon-klon Ubi Jalar Harapan Asal Provinsi Maluku Berdasarkan Potensi Hasil, Adaptabilitas dan Stabilitas Pada Lingkungan Lokal". Dukungan Helen Hetharie (alm,) dan Simon Raharjo yang masing-masing merupakan peneliti utama dan peneliti dalam penelitian ini sangat kami hargai.

\section{DAFTAR PUSTAKA}

BALITKABI, Deskripsi Varietas Unggul Ubi Jalar, 1977-2016. http://balitkabi.litbang.pertanian.go.id/wpcontent/uploads/2016/09/ubijalar.pdf. Diakses 24 Oktober 2018.

[BPS] Badan Pusat Statistik Maluku. 2015. Maluku Dalam Angka. BPS Maluku.

Bari, A., S. Musa, dan E. Syamsuddin. 1974. Pengantar Pemuliaan Tanaman. Departemen Agronomi. Fakultas Pertanian Institut Pertanian Bogor, Bogor.

Fitter, A.H. dan R.K.M. Hay. 1992. Fisiologi Lingkungan Tanaman. Terjemahan S. Andani dan E.D. Purbayanti, Gadjah Mada University Press, Yogyakarta.

Gardner, F., R.B. Pearce, dan R.L Mitchell. 1991. Fisiologi Tanaman Budidaya, terjemahan $\mathrm{H}$. Susilo. Penerbit Universitas Indonesia, Jakarta.

Ginting, E., J.S. Utomo, dan M. Jusuf. 2012. Identifikasi sifat fisik, kimia dan sensoris klon-klon harapan ubi jalar kaya beta karoten. dalam Prosisidng Seminar Nasional. (Eds). Rahmianna, A.A., E. Yusnawan, A. Taufiq, Sholihin, Suharsono, T. Sundari, dan Hermanto. Balai Penelitian Tanaman Aneka Kacang dan Umbi. hlm 612-623.

Goldsworthy, P.R. dan N.M. Fisher. 1992. Fisiologi Tanaman Budidaya Tropik. Gadjah Mada University Press. Yogyakarta.

Handewi, P. dan S. Rachman. 2010. Kajian Keterkaitan Produksi, Perdagangan dan Konsumsi Ubi Jalar untuk Meningkatkan 30\% Partisipasi Konsumsi Mendukung Progam Keanekaragaman Pangan dan Gizi. http://www.anneahira.com/Artikel Umum/Agibisnis.htm. Diakses tanggal 20 April 2018.

International Potato Center. 2000. Stories From The Field International Potato Center, Annual Report 2000. CIP de la papa. Lima, Peru.

Jambormias, E. 2011. Pengukuran Keanekaragaman Genetik [Internet]. [diunduh 26 Agustus 2017]. Tersedia pada: http://www.agrostatfapertaunpatti.blogspot.c om/2011/07/pengukuran-keanekaragamanplasma-nutfah.html. 
Rahayuningsih, S.A. 1997. Panduan karakterisasi dan evaluasi plasma nutfah ubi jalar. Balai Penelitian Tanaman Aneka Kacang dan Umbi. Badan Litbang Pertanian. $31 \mathrm{hlm}$.

Rukmana. 1997. Ubi Jalar, Budidaya dan Pasca Panen. Yogyakarta: Kanisius.

Salisbury, F.B. dan C.W. Ross. 1995. Fisiologi Tumbuhan Jilid III. Penerbit ITB. Bandung

Sarwono, B. 2005. Ubi Jalar: Cara Budi Daya yang Tepat, Efisien dan Ekonomis. Penebar Swadaya, Jakarta.

Setiawati, J., Sudaryono, dan A. Setyono. 1994. Studi Penyimpanan Ubi Jalar Segar. Balai Penelitian Tanaman Pangan Malang. Malang. $5 \mathrm{hlm}$.

Setyono, A.Y., Setiawati, dan Sudaryono. 1993. Penanganan pascapanen ubi jalar. Dalam
Syam M. Hermanto, A. Musaddad (Editor). Prosiding Simposium Penelitian Tanaman Pangan III; Jakarta, 23-25 Agustus 2003.

Sitompul, S.M. dan B. Guritno. 1995. Analisis Pertumbuhan Tanaman. Fakultas Pertanian Universitas Gadjah Mada. Gadjah Mada University Press.

Suwardjono. 2003. Pengaruh Beberapa Jenis Pupuk Kandang Terhadap Pertumbuhan dan Produksi Kacang Tanah. Jurnal Matematika Sains Teknologi 2: 1-5.

Trisnawati, W., R.Y. Made, dan A. Nyoman. 2006. Adaptasi Tiga Varietas Ubi Jalar (Ipomoea batatas L.) Keragaan Komposisi Kimia dan Referensi Panelis. Balai Pengkajian Teknologi Pertanian. Bali. 